Kinerja Sistem Fertigasi Rakit Apung Pada Budi Daya Tanaman Kangkung (Ipomoea reptans Poir.)

\title{
Performance of Floating Raft Fertigation System on Water Spinach Plants (Ipomea reptans Poir.) Cultivation
}

\author{
Rizal Hadyan Fadhlillah ${ }^{1}$, Sophia Dwiratna ${ }^{2}$, Kharistya Amaru ${ }^{2}$ \\ ${ }^{1}$ Program Studi Teknik Pertanian, Fakultas Teknologi Industri Pertanian, Universitas Padjadjaran \\ ${ }^{2}$ Departemen Teknik Pertanian dan Biosistem, Fakultas Teknologi Industri Pertanian, Universitas Padjadjaran \\ Jl. Raya Bandung-Sumedang Km. 21 Jatinangor 43563 \\ *Corresponding Author : sophia.dwiratna@ unpad.ac.id
}

\begin{abstract}
The increase of human population impact to more land needed for residence and has an impact on the decreasing land for agriculture, especially in urban areas. One of solution for farming in urban areas is by utilizing rooftop farming by hydroponic cultivation. The hydroponic system that used in this research is floating raft system. This study aims to determine the performance of the floating raft fertigation system which includes the amount of energy consumption, water, nutrient solution, growth uniformity and yield productivity in water spinach cultivation using floating raft fertigation system for one period of growth. This research was carried out on the rooftop of the building of the Food Industry Technology Department of Padjadjaran University with descriptive analysis method. The parameters measured in this study were the amount of water consumption, nutrition and electrical energy from the floating raft fertigation system that was used and uniformity of the results of plant growth including plant height, root length and plant weight at harvest determined in this study, 16 days after transplanting. Result showed that water consumption for one time growth period water spinach was 300,63 liters; consumption of nutrients was $3860 \mathrm{ml}$ and electricity consumption was $31,816 \mathrm{~kW}$. The uniformity of water spinach plant results of the study was in the category of good. The efficiency of water use was $99.6 \mathrm{~kg} / \mathrm{m}^{3}$ and plant productivity based on research results is 72.8 $\mathrm{kg} / \mathrm{m}^{2}$.
\end{abstract}

Keywords: floating raft system, urban farming, fertigation, irrigation performance, uniformity.

\begin{abstract}
ABSTRAK
Peningkatan populasi manusia berakibat semakin dibutuhkannya lahan untuk tempat tinggal dan berdampak pada semakin berkurangnya lahan untuk pertanian terutama di kawasan perkotaan. Salah satu solusi untuk bercocok tanam di area perkotaan adalah dengan memanfaatkan pertanian atas gedung (rooftop) dengan cara bertanam secara hidroponik. Sistem hidroponik yang digunakan untuk penelitian adalah sistem rakit apung. Penelitian ini bertujuan untuk mengetahui kinerja dari sistem fertigasi rakit apung yang mencakup jumlah konsumsi energi, air, larutan nutrisi, keseragaman tumbuh dan produktivitas hasil panen pada budi daya tanaman kangkung menggunakan sistem fertigasi rakit apung selama satu kali masa pertumbuhan. Penelitian ini dilaksanakan di rooftop gedung Departemen Teknologi Industri Pangan Universitas Padjadjaran dengan metode analisis desktritif. Parameter yang diukur pada penelitian ini adalah jumlah penggunaan air konsumtif, nutrisi dan energi listrik dari sistem fertigasi rakit apung yang digunakan serta keseragaman dari hasil pertumbuhan tanaman meliputi tinggi tanaman, panjang akar dan bobot tanaman ketika panen yang ditetapkan pada penelitian ini yaitu 16 hari setelah pindah tanam. Hasil penelitian menunjukkan bahwa penggunaan air konsumtif selama satu kali masa pertumbuhan adalah 300,63 liter; konsumsi nutrisi sebanyak $3860 \mathrm{ml}$ dan konsumsi energi listrik sebesar 31,816 kW. Keseragaman tanaman hasil penelitian termasuk pada kategori baik hingga baik. Efisiensi penggunaan air yang diperoleh adalah $99,6 \mathrm{~kg} / \mathrm{m}^{3}$ dan produktivitas tanaman berdasarkan hasil penelitian sebesar $72,8 \mathrm{~kg} / \mathrm{m}^{2}$.
\end{abstract}

Kata Kunci: urban farming, fertigasi, rakit apung, kinerja irigasi, keseragaman 


\section{PENDAHULUAN}

Sayuran sebagai makanan pendamping makanan utama menjadi sangat dibutuhkan saat ini, karena semakin banyak orang yang sadar terhadap kesehatan yang dapat ditunjang dengan cara mengkonsumsi sayuran alami dan sehat secara teratur. Salah satu sayuran bergizi serta digemari sebagian besar masyarakat adalah kangkung. Berdasarkan data dari Badan Pusat Statistika (2017), sayuran kangkung merupakan salah satu sayuran favorit di Indonesia dengan total konsumsi nasional sebanyak 1,134 juta ton di tahun 2015 dan 1,232 juta ton per tahun 2016. Dilihat dari konsumsi kangkung yang cukup besar dan meningkat tersebut, maka dapat dikatakan bahwa kebutuhan masyarakat terhadap kangkung semakin meningkat. Produksi kangkung nasional dari tahun 2009 hingga 2013 yang terus mengalami penurunan menjadi masalah yang cukup serius mengingat konsumsi kangkung setiap tahunnya terus meningkat.

Berdasarkan permasalahan tersebut maka munculah berbagai metode tanam yang dapat dilakukan di perkotaan sekalipun akan tetapi masih bisa memproduksi kebutuhan masyararakat, khususnya memproduksi kebutuhan sayuran. Salah satu metodenya adalah budi daya tanaman dengan sistem hidroponik. Keutamaan penanaman hidroponik adalah sangat mungkin untuk dilakukan penanaman di wilayah perkotaan. Pertanian perkotaan merupakan kegiatan pertumbuhan, pengolahan, dan distribusi pangan serta produk lainnya melalui budi daya tanaman dan peternakan yang intensif di perkotaan dan daerah sekitarnya, dan menggunakan (kembali) sumber daya alam dan limbah perkotaan, untuk memperoleh keragaman hasil panen dan hewan ternak (Dwiratna, Bafdal, \& Kendarto, 2017; Paradiso, Buonomo, Dixon, Barbieri, \& De Pascale, 2014; Suryani, 2015)

Menurut (Iqbal, 2016) bertanam secara hidroponik lebih hemat pupuk dan air. Pemberian pupuk pada sistem hidroponik ini sangat efektif karena nutrisi yang diserap oleh akar dan tidak ada yang terbuang percuma. Konsumsi air pada penanaman secara hidroponik ini juga terbilang lebih efisien dibanding bercocok tanam secara konvensional karena air atau larutan nutrisi akan tersirkulasi pada bak penampung dan dialirkan kembali pada tanaman (Iqbal, 2016).

Salah satu metode penanaman dalam sistem hidroponik adalah sistem hidroponik rakit apung. Sistem fertigasi rakit apung atau Floating Raft System adalah teknik menanam tanaman pada suatu rakit berupa panel tanam berupa styrofoam yang dapat mengapung di atas permukaan larutan nutrisi dengan akar menjuntai ke dalam air (Nurrohman, Suryanto, \& Puji, 2014). Sistem hidroponik rakit apung mempunyai kelebihan dari sistem hidroponik lain yaitu lebih sederhana, perawatan instalasi lebih mudah dan murah, optimalisasi pupuk dan air, optimalisasi ruang, serta operasional lebih mudah dan sederhana. Penanaman secara hidroponik salah satunya dapat dilakukan di atap bangunan atau rooftop farming.

Beberapa parameter penting yang harus diperhatikan dalam budi daya tanaman dengan sistem fertigasi rakit apung ini adalah hasil pertumbuhan tanaman, konsumsi energi listrik, konsumsi air dan nutrisi yang dibutuhkan selama satu kali masa tanam. Parameter tersebut sangat perlu diperhatikan agar hasil dari penanaman lebih efektif dan efisien jika dibandingkan dengan hasil dari bercocok tanam secara konvensional.

Hingga saat ini, belum diketahui informasi dasar dari penanaman kangkung secara hidroponik dengan sistem rakit apung yakni informasi mengenai kinerja yang mencakup karakteristik hasil tanaman, kebutuhan air, kebutuhan nutrisi dan total energi listrik yang digunakan selama satu kali masa tanam. Penelitian ini dilakukan agar dapat diketahui karakteristik, konsumsi energi, konsumsi air dan larutan nutrisi selama satu kali masa tanam pada tanaman kangkung dengan sistem fertigasi rakit apung yang hasilnya dapat dibandingkan dengan penanaman secara konvensional maupun dengan sistem fertigasi lain.

\section{BAHAN DAN METODE}

Penelitian dilaksanakan pada bulan September hingga Januari 2019 di rooftop gedung Departemen Teknologi Industri Pangan Universitas Padjadjaran Kecamatan Jatinangor Kabupaten Sumedang, Jawa Barat dengan koordinat $06^{\circ} 55^{\prime} 23,4^{\prime \prime}$ LS dan $107^{\circ} 46^{\prime} 19,33^{\prime \prime}$ BT dan elevasi 794 mdpl.

Alat yang digunakan pada penelitian ini adalah seperangkat instalasi hidroponik rakit apung, pompa, aerator, DO meter, EC meter, alat ukur panjang, thermohygrometer, lux meter dan timbangan analitik. Bahan yang digunakan pada penelitian ini adalah benih tanaman kangkung, media tanam dan nutrisi $\mathrm{AB}$ mix.

Metode yang digunakan pada penelitian ini adalah metode deskriptif analitik, yaitu melakukan pengukuran, pengamatan, perhitungan dan analisis data secara kuantitatif dalam mengamati 
karakteristik, penggunaan energi listrik, air dan larutan nutrisi pada tanaman kangkung sistem fertigasi rakit apung. Jumlah sampel yang digunakan adalah 64 titik pengukuran dari total 182 lubang tanam. Media tanam yang digunakan saat persemaian adalah cocopeat dan media yang digunakan ketika pindah tanam adalah rockwool.

Tahapan pelaksanaan dari penelitian ini adalah sebagai berikut:

\section{a. Persiapan}

Instalasi hidroponik rakit apung yang digunakan dalam penelitian ini memiliki ukuran rangka terluar $350 \mathrm{~cm}$ x 117,5 cm. Rangka terbuat dari baja ringan dan bagian atas rangka dilapisi dengan terpal untuk menampung air. Jarak antar lubang netpot sejauh $15 \mathrm{~cm}$ dan jumlah lubang netpot sebanyak 182 buah.

\section{b. Pertumbuhan Tanaman}

Tahap pertumbuhan tanaman ini meliputi pembuatan larutan nutrisi AB Mix, persemaian, pindah tanam dan pertumbuhan tanaman pada instalasi rakit apung. Larutan nutrisi yang digunakan pada penelitian ini menggunakan nutrisi $\mathrm{AB}$ Mix yang dilarutkan pada tandon air. Kebutuhan nutrisi tanaman kangkung menurut (Iqbal, 2016) adalah antara 1050 hingga 1400 ppm atau nilai EC sebesar 2,1 hingga $3 \mathrm{mS} / \mathrm{cm}$. Proses penyemaian dilakukan secara manual di sebuah baki. Benih kangkung sebelum ditaburkan pada cocopeat direndam terlebih dahulu selama 24 jam, tujuannya adalah supaya benih kangkung lebih cepat pecah biji. Tahapan Penyemaian berlangsung selama 7 hingga 14 hari tergantung dari siap atau tidaknya bibit untuk pindah tanam.

Pindah tanam dilakukan dengan mencabut akar kangkung dari cocopeat lalu dipindahkan pada rockwool. Setelah itu rockwool yang sudah terisi bibit kangkung tersebut disimpan pada net pot dan dipindahkan tanam ke sistem hidroponik rakit apung hingga masa panen. Kangkung yang telah layak panen memiliki daun yang tumbuh subur, pangkal daun tampak sehat, serta ketinggian tanaman seragam dan merata. Menurut (Susila, 2006) kangkung darat bisa dipanen apabila secara visual pertumbuhan batangnya sudah besar, berdaun banyak, dan tinggi tanamannya sudah mencapai $20-25 \mathrm{~cm}$, meskipun beberapa pendapat menyatakan bahwa kangkung sudah bisa dipanen pada umur sekitar 25 - 27 HST.

\section{Parameter Pengukuran} adalah:

\section{Parameter Penunjang}

Parameter penunjang yang akan dilakukan pada penelitian ini yaitu pengukuran suhu lingkungan, kelembaban dan intensitas cahaya matahari yang di ukur setiap satu jam pada pukul 07.00, 12.00 dan 17.00. Data tersebut ditunjang juga dengan pengukuran suhu larutan nutrisi, Electrical Conductivity (EC), $\mathrm{pH}$ dan oksigen terlarut (DO) 64 sampel yang sudah ditentukan.

\section{Parameter Utama}

1. Pengukuran Tinggi Tanaman Kangkung

Pengukuran tinggi tanaman dilakukan selama tiga hari sekali pada 64 titik tanaman yang telah ditentukan. Nilai tinggi tanaman diukur bermula dari pangkal batang yang berada di permukaan media tanam sampai bagian tanaman tertinggi.

2. Pengukuran Konsumsi Air

Pengukuran konsumsi air dilakukan dengan cara mangukur tinggi air di tandon untuk mengetahui konsumsi air menggunakan mistar plastik. Pengukuran dilakukan tiga kali sehari yaitu pada pukul $07.00 ; 12.00$ dan 17.00. Jika tinggi air sudah mencapai batas minimal air yang sejajar dengan pompa, air akan diisi kembali hingga ketinggian $30 \mathrm{~cm}$ pada tandon air. Angka yang diperoleh kemudian dimasukan pada persamaan yang diperoleh dari penelitian pendahuluan. Persamaan yang digunakan adalah:

Keterangan:

$$
\mathrm{y}=2,6684 \mathrm{x}-2,8519
$$

$\mathrm{y}=$ Konsumsi Air

$\mathrm{x}=$ Penurunan tinggi muka air tandon

3. Pengukuran Konsumsi Nutrisi

Nutrisi AB mix yang digunakan pada penelitian ini akan dikalkulasikan setiap penambahannya dan dikonversikan pada biaya pembelian nutrisi $\mathrm{AB}$ mix tersebut. Penambahan tersebut akan dikurangi dengan sisa nutrisi yang masih tersisa saat pemanenan. Perhitungan sisa nutrisi menggunakan perbandingan antara volume air total dan nutrisi yang ditambahkan.

4. Perhitungan Konsumsi Listrik

Listrik yang digunakan dari pompa dan aerator selama satu masa tanam akan dikalkulasikan dan dikonversikan pada biaya listrik. Konsumsi Energi ini merupakan jumlah dari energi listrik yang terdiri dari penggunaan pompa dan aerator. Dihitung dengan menggunakan rumus:

Total Konsumsi Listrik $(\mathrm{kWh})=\mathrm{P} \times \mathrm{T} \ldots$ (2)

Keterangan:

$\mathrm{P} \quad=$ Daya alat listrik (pompa dan aerator)

$\mathrm{T}$ = Lama waktu pemakaian (dalam jam) 


\section{Analisis Data}

1. Perhitungan Evapotranspirasi

Evapotranspirasi potensial (ETo) diperoleh dengan menggunakan metode Penman Monteith basis suhu dengan bantuan aplikasi Cropwat 8.0. Metode Penman-Monteith yang digunakan terdapat dalam (Allen, Pereira, Raes, \& Smith, 1998b) seperti pada persamaan berikut:

$$
\text { ETo }=\frac{0,4018 \Delta\left(R_{n}-G\right)+\gamma \frac{900}{T+273} u_{2}\left(e_{s}-e_{a}\right)}{\Delta+\gamma\left(1+0,34 u_{2}\right)} \ldots .
$$

Keterangan:

$$
\begin{array}{ll}
\text { ETo } & =\text { evapotranspirasi potensial }(\mathrm{mm} / \mathrm{hari}) \\
\Delta & =\text { tekanan uap jenuh }\left(\mathrm{kPa} /{ }^{\circ} \mathrm{C}\right) \\
\mathrm{G} & =\text { flux panas tanah }\left(\mathrm{MJ} / \mathrm{m}^{2} / \mathrm{hari}\right) \\
\mathrm{Rn} & =\text { total radiasi bersih }\left(\mathrm{MJ} / \mathrm{m}^{2} / \text { hari }\right) \\
\gamma & =\text { psikometrik }\left(\mathrm{kPa} /{ }^{\circ} \mathrm{C}\right) \\
\mathrm{T} & =\text { suhu rata-rata harian }\left({ }^{\circ} \mathrm{C}\right) \\
\mathrm{U}_{2} & =\text { kecepatan angin pada ketinggian } 2 \mathrm{~m} \mathrm{di} \\
& \text { atas tanah }(\mathrm{m} / \mathrm{det})
\end{array}
$$

$($ es - ea $)=$ Perbedaaan tekanan uap jenuh $(\mathrm{KPa})$

2. Koefisien Tanaman

Nilai koefisien tanaman dapat dihitung dengan persamaan berikut:

$$
\mathrm{Kc}=\mathrm{ETc} / \mathrm{ETo}
$$

Keterangan:

$$
\begin{array}{ll}
\text { Kc } & =\text { Koefisien Tanaman } \\
\text { Etc } & =\text { Penggunaan air konsumtif }(\mathrm{mm} / \mathrm{hari}) \\
\text { ETo } & =\text { Evapotranspirasi acuan }(\mathrm{mm} / \mathrm{hari})
\end{array}
$$

3. Kinerja Keseragaman Sistem Rakit Apung Keseragaman yang dihitung pada penelitian ini diantaranya adalah keseragaman tinggi tanaman, keseragaman panjang akar dan keseragaman bobot tanaman saat masa panen. (Sapei, 2003) menyatakan bahwa nilai CU (Coefficient Uniformity) haruslah lebih besar dari $80 \%$. Nilai CU yang rendah dapat dijadikan indikator bahwa banyak kehilangan air dan nilai efektifitas yang rendah. Menurut (Michael, 2001) yang menyatakan bahwa koefisien keseragaman (Coefficient Uniformity) merupakan salah satu penentu dalam efisiensi irigasi yang dihitung dengan persamaan koefisien keseragaman irigasi (CU/ Coefficient Uniformity) dengan persamaan:

$$
\mathrm{Cu}=100\left(1-\frac{\sum|\mathrm{xi}-\bar{x}|}{n \bar{x}}\right) \ldots \ldots(5)
$$

Keterangan:

$$
\begin{array}{ll}
\mathrm{Cu}= & \text { Tingkat Keseragaman }(\%) \\
\mathrm{n} & =\text { Jumlah pengamatan atau jumlah } \\
& \text { jumlah } \\
\mathrm{x} & =\text { Nilai rata-rata dari keseragaman } \\
\mathrm{xi} & =\text { Parameter Keseragaman titik ke - } \\
& (1,2,3,4 \mathrm{dst})
\end{array}
$$
$\sum|\mathrm{xi}-\bar{x}|=\underset{\text { Jumlah dari deviasi absolut dari rata- }}{\text { rata pengukun }}$
(4.

4. Efisiensi Penggunaan Air (WUE)

Menurut (Bafdal \& Dwiratna, 2018), Efisiensi penggunaan air (WUE) adalah perbandingan dari hasil panen yang dihasilkan dengan air yang dibutuhkan. Efisiensi penggunaan air/ Water Used Efficiency (WUE) dapat dihitung dengan menggunakan persamaan berikut.

$$
\text { WUE }\left(\mathrm{kg} \cdot \mathrm{m}^{-3}\right)=\frac{\text { Hasil Produksi }}{\text { Total Penggunaan Air }} \text {. }
$$

Hasil produksi dinyatakan dalam satuan $\mathrm{kg}$, total air yang digunakan untuk menghasilkan produk dinyatakan dalam $\mathrm{m}^{3}$ serta efisiensi penggunaan air (WUE) dinyatakan dalam satuan $\mathrm{kg} / \mathrm{m}^{3}$.

\section{HASIL DAN PEMBAHASAN}

\section{Pengamatan Penunjang}

Pengamatan penunjang meliputi pengukuran mikroklimat (Suhu, kelembaban dan intensitas cahaya) serta kualitas nutrisi yang mencakup pengukuran nilai suhu, EC, pH, dan DO larutan nutrisi. Menurut (Bafdal, Dwiratna, \& Kendarto, 2018), pada budi daya dengan sistem hidroponik kondisi lingkungan seperti suhu, kelembaban relatif, dan intensitas cahaya, bahkan faktor curah hujan dapat dioptimalkan sehingga serangan hama dapat diminimalkan.

\section{Suhu Lingkungan Rata-rata}

Pengukuran suhu lingkungan ini merupakan pengukuran rata-rata dari suhu terendah dan tertinggi pada setiap harinya. Pencatatan dilakukan setiap pukul 07.00 untuk mendapatkan nilai suhu dan kelembaban maksimum dan minimum. Hasil pengamatan suhu lingkungan selama masa penelitian disajikan pada grafik berikut.

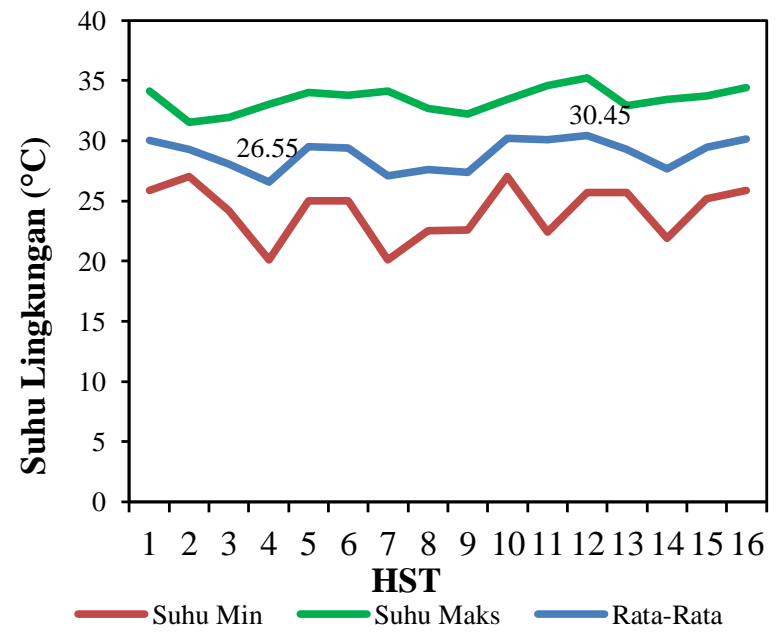


Gambar 1. Suhu Lingkungan Selama Penelitian

Gambar 1 menunjukan nilai suhu rata bahwa selama 16 hari penelitian, rata-rata suhu tertinggi berada pada hari ke 16 dengan nilai sebesar $30,15^{\circ} \mathrm{C}$ dan terendah pada hari ke 4 yaitu $26,55^{\circ} \mathrm{C}$. Secara umum, rentang suhu selama penelitian ini kebanyakan berada pada rentang 27 hingga $30^{\circ} \mathrm{C}$. Faktor lingkungan tempat tumbuh tanaman yang penting bagi pertumbuhan salah satunya oleh faktor suhu lingkungan. Menurut (Palada \& Chang, 2003) suhu udara ideal untuk pertumbuhan optimal tanaman kangkung adalah 25 hingga $30^{\circ} \mathrm{C}$, sedangkan pada suhu di bawah $10^{\circ} \mathrm{C}$ tanaman akan rusak. Berdasarkan pada Gambar 5, dapat dikatakan bahwa suhu lingkungan tempat penelitian masih dapat dikatakan ideal untuk penanaman kangkung.

Suhu udara yang terlalu tinggi dapat menyebabkan tingginya transpirasi atau penguapan pada tanaman yang menyebabkan tanaman kehilangan banyak air. Jumlah air yang keluar akibat evapotranspirasi lebih besar dengan jumlah air yang diserap oleh akar tanaman. Keadaan jumlah air dalam tanaman yang tidak seimbang menyebabkan mengalami kelayuan. Sedangkan suhu udara yang terlalu rendah dapat menghambat pertumbuhan tanaman dan berakibat pada menurunnya produksi. Tanaman kangkung dapat hidup dengan baik di daratan tinggi maupun daratan rendah sehingga hampir di seluruh tanah air kita tanaman ini dapat dibudidayakan.

\section{Kelembaban Lingkungan Rata-rata}

Pengukuran kelembaban lingkungan ini merupakan pengukuran rata-rata dari kelembaban terendah dan tertinggi pada setiap harinya. Pencatatan dilakukan setiap pukul 07.00 untuk mendapatkan nilai kelembaban maksimum dan minimum. Hasil pengamatan kelembaban lingkungan selama masa penelitian disajikan pada Gambar 2.

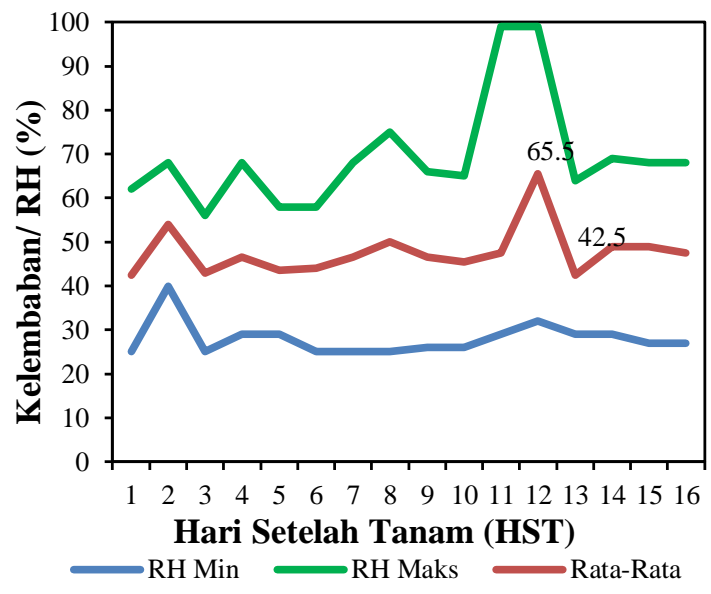

Gambar 2. Kelembaban Lingkungan Selama Penelitian

Gambar tersebut menunjukkan bahwa ratarata kelembaban lingkungan tertinggi adalah pada hari ke 12 dengan rata-rata $65,5 \%$ dan terendah pada hari pertama yaitu $37 \%$. Nilai kelembaban maksimal berada pada hari ke 11 dan 12 yang sebesar 99\%. Hal tersebut terjadi karena pada kedua hari tersebut turun hujan sehingga nilai kelembaban cenderung tinggi. Jika dibandingkan dengan nilai suhu yang ditunjukkan pada Gambar 1 , peningkatan dan penururunan nilai kelembaban dan suhu lingkungan cenderung berbanding terbalik. Hal ini diperkuat juga dengan pernyataan (Mori, 2006) yang menyatakan bahwa variasi kelembaban bertentangan dengan variasi suhu.

Pengaruh kelembaban relatif (relative humidity) terhadap pertumbuhan menurut (Komalasari, 2016) yaitu mempengaruhi pertumbuhan dan produktivitas tanaman, fotosintesis, transpirasi, pembungaan serta perkembangan hama dan penyakit. Kangkung darat sangat kuat menghadapi panas terik dan kemarau panjang dengan kelembaban $60 \%$. $\mathrm{RH}$ yang terlalu rendah mengakibatkan laju transpirasi tanaman terhambat sehingga tanaman menjadi kekeringan. $\mathrm{RH}$ yang terlalu tinggi akan memicu terjangkitnya suatu penyakit pada tanaman sehingga dapat menurunkan hasil panen bahkan kematian tanaman (Palada \& Chang, 2003).

\section{Intensitas Cahaya Matahari}

Intensitas cahaya berkaitan dengan keadaan di mana cahaya berada dalam jumlah kebutuhan yang cukup bagi tanaman untuk berfotosintesis. Gambar di bawah ini menunjukkan nilai intensitas cahaya selama masa tanam (setelah pindah tanam). 


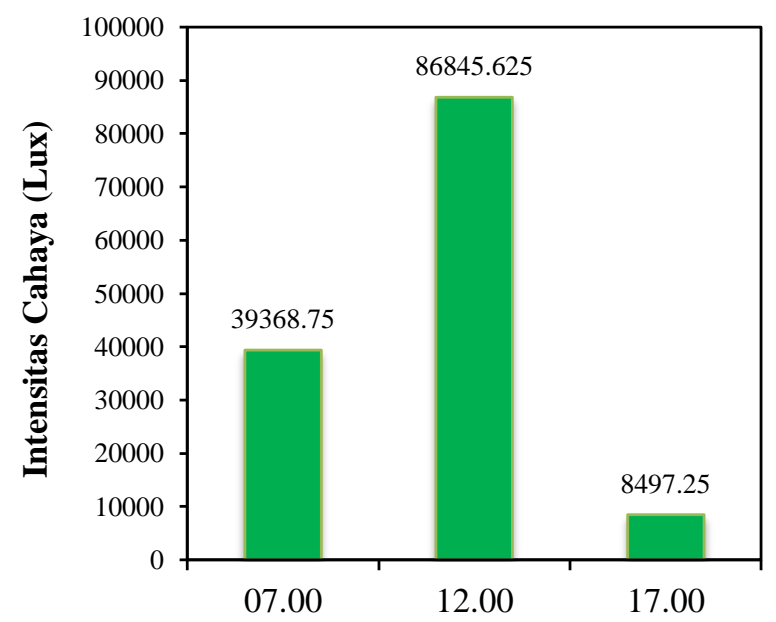

Gambar 3. Intensitas Cahaya Selama Penelitian

Berdasarkan pada Gambar 3, nilai rata-rata intensitas cahaya terbesar adalah pada pukul 12.00 dan terendah pada pukul 17.00. Rata-rata intensitas cahaya pada pukul 07.00 adalah 39368,75 lux, pada pukul 12.00 sebesar 86845,625 lux dan pukul 17.00 adalah sebesar 8497,25 lux. Intensitas cahaya optimal untuk tanaman kangkung menurut Dinas Pertanian dan Pangan Kabupaten Badung adalah pada rentang 4305,56 - 8611,13 sehingga dapat dikatakan tanaman kangkung tidak membutuhkan cahaya yang terlalu panas. Intensitas cahaya matahari yang optimal akan mempengaruhi aktivitas stomata untuk menyerap $\mathrm{CO}_{2}$, semakin tinggi intensitas cahaya matahari yang diterima oleh permukaan tanaman, maka jumlah absorpsi $\mathrm{CO}_{2}$ relatif semakin tinggi pada kondisi curah hujan yang cukup (Nazaruddin, 2003).

Lokasi penelitian sangat mempengaruhi intensitas cahaya matahari yang menyinari tanaman. Saat pelaksanaan penelitian kondisi rooftop yang terbuka dari samping dan atap dari rooftop yang yang masih bagus sehingga tidak menghambat cahaya yang menyinari tanaman. Kondisi atap jika kotor atau tempat penelitian yang terutup akan mempengaruhi intensitas cahaya matahari yang menyinari tanaman. Tanaman yang kekurangan cahaya matahari akan mengalami etiolasi yaitu menjadi berwarna kuning serta memiliki batang yang panjang namun kurus dan terlihat kurang segar. Tanaman yang mendapatkan cahaya cukup akan membentuk warna hijau yang berhubungan dengan pembentukan klorofil, perangsang fotosintesis dan memiliki struktur normal (Komalasari, 2016).

\section{Suhu Larutan Nutrisi}

Suhu larutan yang terlalu tinggi akan mempersulit tanaman untuk menyerap unsur hara.
Larutan nutrisi lebih baik dijaga pada kisaran suhu $25-30^{\circ} \mathrm{C}$ jika melebihi dari suhu tersebut maka air tersebut tergolong pada air hangat dan menyebabkan pathogen hidup di larutan nutrisi berpengaruh pada berkurangnya kadar oksigen terlarut yang dibutuhkan akar tanaman (Nugrahani, 2018). Suhu larutan yang terlalu tinggi menyebabkan pertumbuhan tanaman terganggu. Menurut (Morgan, 2000), suhu larutan di atas 26 ${ }^{\circ} \mathrm{C}$ menyebabkan pertumbuhan dan penyebaran penyakit yang disebabkan oleh jamur, salah satunya adalah pembusukan akar. Gambar 8 menunjukkan hasil rata-rata pengukuran suhu larutan nutrisi selama 16 hari masa penelitian.

Berdasarkan hasil penelitian, nilai suhu lingkungan pada hari pertama ini sebesar $27,65^{\circ} \mathrm{C}$. Secara umum, nilai suhu larutan nutrisi paling tinggi terjadi pada pukul 12.00 karena dipengaruhi oleh suhu lingkungan yang sedang mencapai titik terpanasnya. Sementara suhu nutrisi terendah cenderung pada pukul 07.00 karena suhu lingkungan juga sedang rendah. Rata-rata suhu terpanas pada pukul 07.00 terjadi pada hari ke tiga dengan nilai suhu $26,69^{\circ} \mathrm{C}$. Rata-rata suhu terpanas pada pukul 12.00 terjadi pada hari ke empat dengan nilai suhu $30,52^{\circ} \mathrm{C}$ dan pada pukul 17.00 adalah sebesar $29^{\circ} \mathrm{C}$ pada hari pertama. Suhu lingkungan dapat dikatakan mempengaruhi suhu larutan nutrisi, karena terjadi transfer panas dari lingkungan ke larutan nutrisi yang berada di dalam tandon.

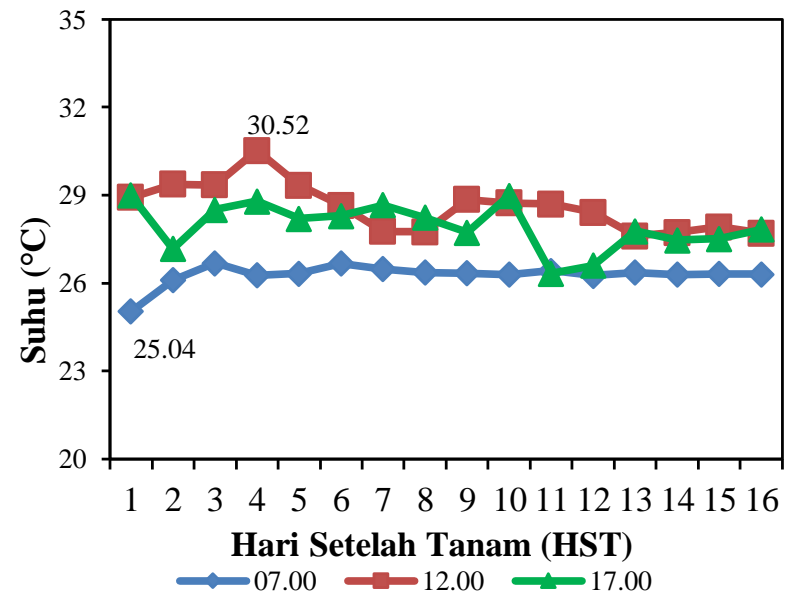

Gambar 4. Suhu Larutan Nutrisi Selama Penelitian

Besaran nilai suhu larutan nutrisi dipengaruhi oleh suhu lingkungan Hasil penelitian dari (Widianty, 2016) menyebutkan bahwa terjadi kenaikan suhu, baik suhu udara maupun suhu larutan nutrisi maka nilai EC pun ikut naik namun suhu tidak terlalu mempegaruhi $\mathrm{pH}$. Ketika terjadi 
kenaikan suhu, baik suhu udara maupun suhu larutan nutrisi maka nilai EC pun ikut naik. Secara lebih lengkap akan disajikan pada bahasan selanjutnya.

\section{Nilai Daya Hantar Listrik (EC) Larutan Nutrisi}

Selama masa pertumbuhan tanaman harus memperoleh nutrisi yang cukup agar pertumbuhan dan hasil produksi optimum. Pemberian larutan nutrisi yang tidak teratur dapat mengurangi hasil produksi tanaman. Salah satu faktor penting yang mempengaruhi kualitas unsur hara harus diperhatikan dalam pemberian nutrisi adalah nilai electrical conductivity (EC). Hasil pengukuran nilai EC selama masa penelitian disajikan pada gambar di bawah ini.

Nilai EC pada awal mula penelitian ini sebesar 2,21 ms/cm. Menurut (Iqbal, 2016), nutrisi yang ideal untuk tanaman kangkung berada pada rentang 1050 sampai dengan 1400 ppm atau 2,1 sampai $2,8 \mathrm{mS}$. Hasil rata-rata pengukuran nilai EC pada penelitian ini adalah berada pada rentang 2,16 sampai dengan 2,44 $\mathrm{mS}$ dengan nilai rata-rata 2,3 $\mathrm{mS}$. Nilai EC tertinggi ini berada pada hari ke 14 . Nilai EC pada pukul 07.00 memiliki rata-rata sebesar 2,28 mS/cm, nilai EC pada pukul 12.00 memiliki rata-rata $2,33 \mathrm{~ms} / \mathrm{cm}$ dan pukul 17.00 sebesar $2,28 \mathrm{~ms} / \mathrm{cm}$.

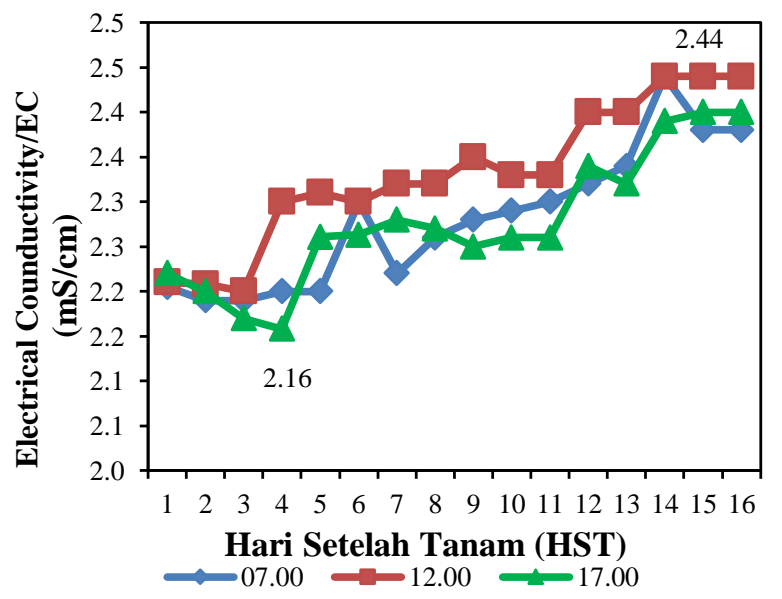

Gambar 5. EC Larutan Nutrisi Selama Penelitian

Berdasarkan hasil pengukuran nilai suhu dan EC larutan nutrisi pada Gambar 4 dan 5, nilai suhu dan EC cenderung berbanding lurus. Menurut Cometti et al., dalam (Muharomah, Setiawan, \& Purwanto, 2017) menyatakan bahwa EC bergantung pada suhu larutan nutrisi. Jika suhu meningkat, resistansi larutan akan menurun seiring dengan berjalannya arus listrik, sehingga meningkatkan konduktivitas. Konduktivitas listrik yang tinggi dari larutan nutrisi dapat menurunkan kemungkinan penyerapan air oleh tanaman dan mengurangi fotosintesis.

Menurut (Sutiyoso, 2018), peningkatan nilai EC mempunyai sisi positif dan negatif. Nilai positifnya diantaranya adalah agar lebih cepat masa penanaman, bobot tanaman meningkat dan umur simpan tanaman yang lebih panjang. Namun, ada juga dampak negatif jika menggunakan nilai EC yang terlalu tinggi yaitu dapat menyebabkan terjadinya fitotoksisitas atau keracunan tanaman. Keracunan pada tanaman ini terjadi apabila kadar nutrisi yang diberikan melebihi nilai ambang batas fitotoksisitas tanaman tersebut. Gejala ini ditandai dengan daun yang terlihat gosong sebagiannya.

\section{Derajat Keasaman (pH) Larutan Nutrisi}

Pengontrolan $\mathrm{pH}$ larutan nutrisi bertujuan agar perubahan yang terjadi dalam penyerapan air dan unsur hara (ion nutrisi) oleh tanaman dapat dibandingkan setiap minggunya. Menurut (Sutiyoso, 2018) pada pH nutrisi yang optimal, semua unsur berada dalam kondisi kelarutan yang sangat baik sehingga nutrisi lebih mudah diserap oleh akar. Di samping itu, pH larutan nutrisi juga berperan penting dalam ketersediaan garam mineral. Hasil pengukuran $\mathrm{pH}$ saat penelitian terdapat pada gambar di bawah ini.

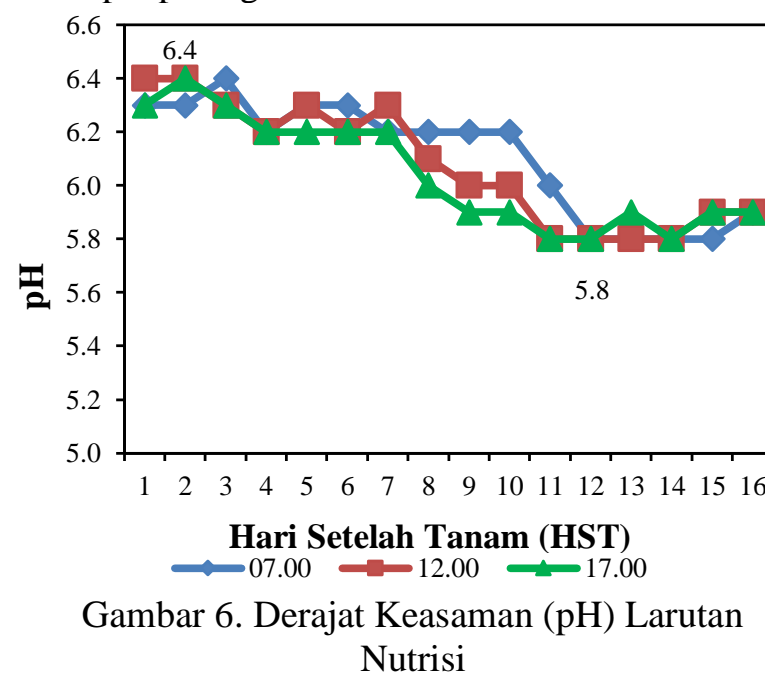

Hasil pengukuran $\mathrm{pH}$ pada penelitian ini memiliki batas terendah 5,8 dan batas tertinggi 6,4 dengan rata-rata pH 6,1. Menurut (Sutiyoso, 2018), pada umumnya nilai $\mathrm{pH}$ untuk budi daya secara hidroponik idealnya berada pada rentang 5,5-6,5 dengan nilai optimum 6,0. Di bawah $\mathrm{pH} 5,5$, beberapa unsur mulai mengendap, tidak dapat diserap oleh akar, akhirnya pada beberapa jenis tanaman akan menunjukkan gejala defisiensi unsur tertentu. Beberapa unsur mulai mengendap pada $\mathrm{pH}$ di atas 6,5 dan berakitbat tidak dapat diserap oleh akar. Berdasarkan pada pendapat tersebut, 
maka dapat dikatakan nilai $\mathrm{pH}$ selama masa penelitian ini terbilang cukup baik karena masih berada pada rentang ideal $\mathrm{pH}$ untuk hidroponik.

Menurut hasil dari penelitian (Widianty, 2016)menyebutkan bahwa nilai pH tidak terlalu dipengaruhi oleh suhu larutan nutrisi, namun cenderung lebih dipengaruhi oleh nilai EC. Nilai $\mathrm{pH}$ dan EC ini berbanding terbalik, ketika nilai $\mathrm{pH}$ larutan nutrisi tinggi, maka nilai EC akan cenderung rendah dan begitu pun sebaliknya. Hal tersebut karena ketika nilai EC semakin meningkat maka larutan nutrisi semakin pekat. Kandungankandungan yang terdapat dalam AB mix cenderung akan membuat larutan semakin asam ketika dipekatkan.

\section{Dissolved Oxygen (DO) Larutan Nutrisi}

Parameter selanjutnya yang diukur adalah nilai oksigen terlarut atau yang selanjutnya disebut DO. Berdasarkan hasil penelitian, nilai DO ratarata selama penelitian adalah sebesar 6,57 mg/L. Menurut (Ningrum, Triyono, \& Tusi, 2014), nilai DO pada larutan nutrisi dianggap sangat baik apabila berada pada nilai sekitar $8 \mathrm{mg} / \mathrm{l}$, namun tanaman masih bisa hidup cukup baik pada nilai DO sekitar 4 mg/L. Menurut (Bafdal, Dwiratna, \& Kendarto, 2017) oksigen terlarut pada larutan nutrisi perlu dijaga sehingga respirasi akar tanaman dapat optimal.

Penelitian ini menggunakan aerator yang dihubungkan dengan enam buah batu aerasi yang di bagi ke berbagai titik pada sistem. Hasil pengukuran nilai DO pada masa penelitian disajikan pada gambar berikut ini.

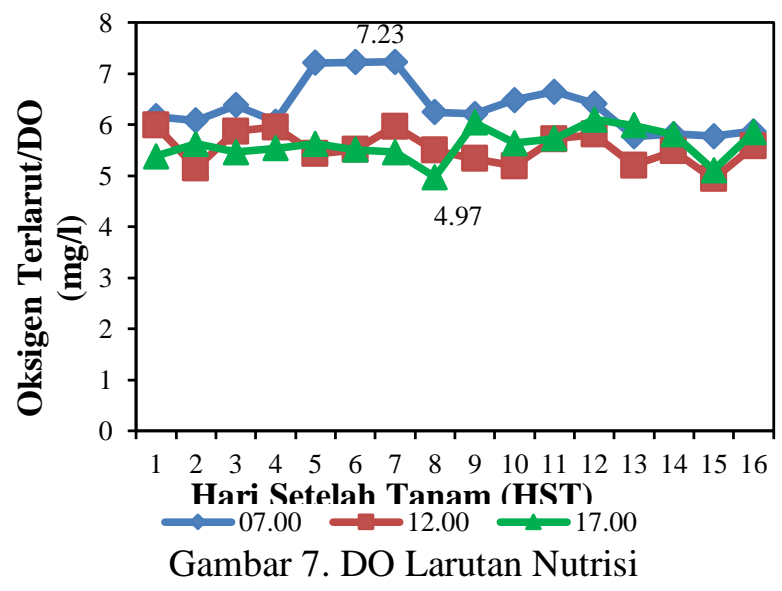

Berdasarkan pada Gambar 7, nilai DO terendah pada umumnya adalah ketika pukul 12.00 dan tertinggi pada pukul 07.00. Nilai DO tertinggi adalah pada hari ke tujuh pada pukul 07.00 dengan nilai 7,23 mg/l dan terendah pada hari ke 15 pukul 12.00 dengan nilai DO sebesar 4,94 mg/l. Merujuk pada pendapat di atas yang mengatakan bahwa tanaman idealnya mendapat oksigen terlarut sebesar $4-8 \mathrm{mg} / \mathrm{l}$, maka hasil dari penelitian ini masih termasuk ke dalam kondisi ideal karena nilai DO berada pada rentang 4,94 - 7,23 mg/l dengan rata-rata 6,57 .

Berdasarkan pada Grafik hasil pengukuran DO, nilai DO umumnya lebih besar pada pukul 07.00 dan cenderung lebih rendah pada pukul 12.00. Hal tersebut dapat dikatakan bahwa nilai DO terpengaruh pada nilai suhu larutan nutrisi. Berbeda dengan nilai EC yang berbanding lurus dengan suhu, nilai DO berdasarkan penelitian ini cenderung berbanding terbalik dengan suhu larutan nutrisi.

Larutan nutrisi pada sistem rakit apung ini seluruhnya tertutup oleh styrofoam sehingga tidak adanya udara bebas pada larutan nutrisi dan akar sepenuhnya terendam yang dapat berdampak pada rendahnya kandungan oksigen dalam air atau DO. Menurut (Kurniasih, 2011), keberadaan oksigen dalam sistem hidroponik sangat penting. Rendahnya oksigen menyebabkan permeabilitas membran sel menurun, sehingga dinding sel makin sulit untuk ditembus nutrisi.

\section{Parameter Utama \\ Tinggi Tanaman}

Tinggi tanaman ini diukur setiap tiga hari sekali dengan tujuan agar cukup banyak data yang diperoleh selama satu kali masa tanam kangkung yang terbilang cukup singkat. Hasil pertumbuhan tinggi tanaman kangkung terdapat pada Gambar 8.

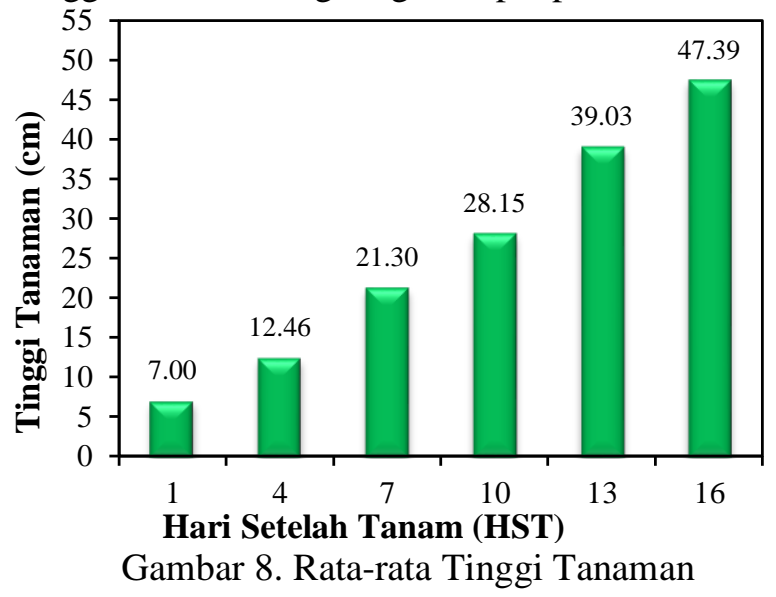

Berdasarkan pada hasil pengukuran pada Gambar 8, nilai pertumbuhan tanaman kangkung untuk setiap pengukurannya selalu bertambah. Jika di rata-ratakan, total pertumbuhan kangkung ini untuk setiap pengukurannya adalah $8 \mathrm{~cm}$ untuk setiap pengukuran. Unsur hara makro dalam nutrisi AB Mix sangat berpengaruh dalam pertumbuhan tanaman, terutama unsur hara $\mathrm{N}$ dan $\mathrm{P}$ (Hidayati, 
Rosawanti, Yusuf, \& Hanafi, 2017). Menurut (Subandi, Salam, \& Frasetya, 2014), pertumbuhan tanaman dalam hidroponik juga diikuti oleh berbagai faktor yang mempengaruhinya, seperti $\mathrm{pH}$ larutan nutrisi. Nilai $\mathrm{pH}$ cenderung mempengaruhi ketersediaan unsur hara pada larutan nutrisi.

Berdasarkan pada penelitian (Kresna, Sukerta, \& Suryana, 2013), yang meneliti pertumbuhan kangkung di secara konvensional dengan media tanah alluvial, hasil tinggi tanaman kangkung berjenis Bangkok pada minggu kedua mencapai tinggi rata-rata $12,8 \mathrm{~cm}$. Sedangkan pada penelitian dengan sistem fertigasi rakit apung ini pada minggu ke dua sudah melebihi $39,1 \mathrm{~cm}$. Penelitian tersebut mengunakan pupuk kandang, sedangkan yang digunakan pada penelitian ini adalah pupuk $\mathrm{AB}$ mix.

Peningkatan tinggi tanaman kangkung dapat disebabkan oleh beberapa faktor seperti nutrisi yang diberikan. Kesesuaian nutrisi yang diberikan dengan kebutuhan dan umur tanaman sangat berpengaruh terhadap pertumbuhan tanaman.

\section{Penggunaan Air Konsumtif}

Penggunaan air konsumtif atau konsumsi air diartikan sebagai jumlah total air yang digunakan baik itu dikonsumsi tanaman maupun untuk proses evapotranspirasi. Besar kebutuhan air untuk pertumbuhan tanaman ditentukan oleh jenis tanaman, fase pertumbuhan tanaman dan faktor iklim (Dwiratna \& Bafdal, 2016).

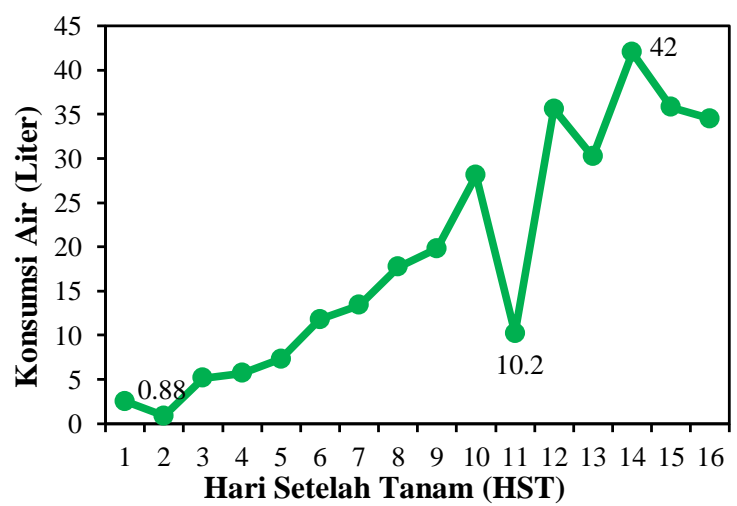

Gambar 9. Penggunaan Air Konsumtif

Menurut (Bafdal, Dwiratna, Kendarto, \& Suryadi, 2017), nilai penggunaan air konsumtif per hari diperoleh dari pengurangan volume larutan nutrisi pada hari sebelumnya dengan volume larutan nutrisi pada hari pengukuran. Berdasarkan pada Gambar 9, jumlah penggunaan air pada sistem fertigasi rakit apung ini cenderung meningkat seiring dengan bertambahnya umur tanaman, namun, pada hari ke 11, penggunaan air konsumtif menurun cukup drastis dari semula 28,1 liter pada hari ke 10 menjadi 10,2 liter di hari ke 11. Hal tersebut disebabkan karena pada hari itu terjadinya hujan sehingga mempengaruhi nilai evapotranspirasi yang terjadi dan berakibat pada rendahnya atau menurunnya penggunaan air konsumtif. Total penggunaan air konsumtif selama masa tanam ini adalah 300,63 liter dengan rata-rata penggunaan air konsumtif sebanyak 18,79 liter per harinya. Analisis dari penggunaan air konsumtif ini dapat digunakan untuk menghitung evapotranspirasi dan koefisien tanaman.

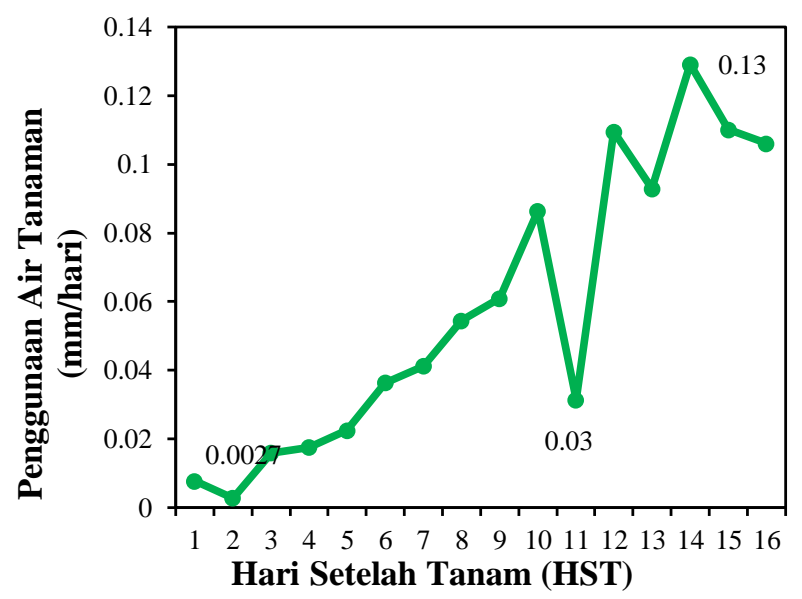

Gambar 10. Penggunaan Air Tanaman

Nilai penggunaan air konsumtif per tanaman didapat dari penggunaan air konsumtif per tanaman seperti pada Gambar 9 namun sudah dibagi dengan jumlah total luas netpot dan total jumlah tanaman. Jumlah penggunaan air konsumtif adalah sebanyak 300,63 liter atau $300,63 \times 10^{6} \mathrm{~mm}^{3}$. Satu netpot terisi oleh 5 buah tanaman kangkung, total netpot adalah 182 netpot sehingga total tanaman adalah 910 buah. Nilai penggunaan air konsumtif per tanaman selama 16 hari masa tanam disajikan pada gambar berikut.

Dilihat pada Gambar 9 dan Gambar 10, penurunan dan kenaikan nilai penggunaan air tanaman ini sangat berkaitan dengan nilai penggunaan air konsumtif pada Gambar 9 karena nilai penggunaan air tanaman ini merupakan hasil pembagian penggunaan air menyeluruh dengan jumlah luas netpot dan jumlah total tanaman.

\section{Evapotranspirasi Potensial (ETo)}

Nilai evapotranspirasi potensial menggambarkan potensi kehilangan air pada lokasi penelitian yang disebabkan oleh kondisi iklim. Evapotranspirasi potensial (ETo) diduga dengan menggunakan metode Penman Monteith dengan basis suhu dengan menggunakan aplikasi Cropwat 8.0 (Allen, Pereira, Raes, \& Smith, 1998a; 
Dwiratna et al., 2017). Metoda Penman Monteith merupakan metode pendugaan evapotranpirasi potensial yang direkomendasikan oleh FAO. Dwiratna \& Bafdal, 2016, menyatakan bahwa metode ini adalah salah satu metode pendugaan evapotranspirasi potensial yang memiliki tingkat kesalahan perhitungan pada musim panas sebesar $10 \%$, dan $20 \%$ sehingga dapat dikatakan sebagai metode terbaik dari sekian banyak metode yang ada. Gambar di bawah ini menunjukkan hasil perhitungan nilai ETo selama 16 hari penelitian.

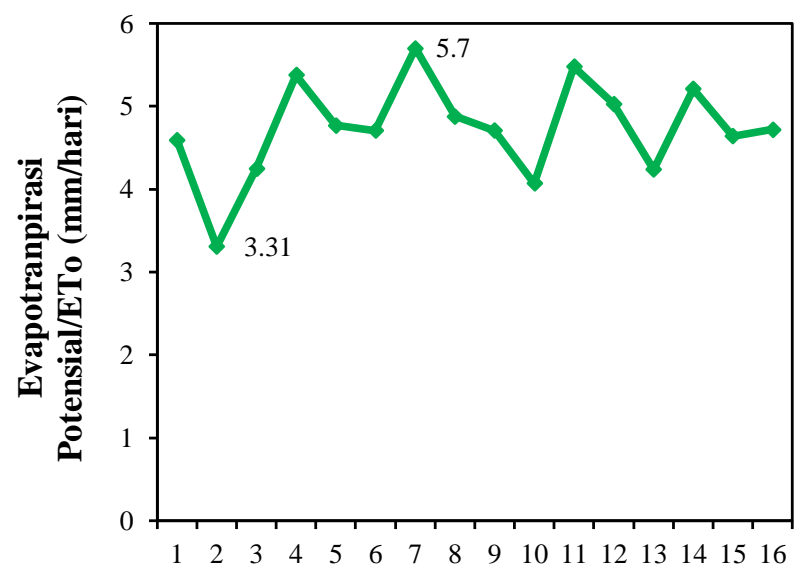

Hari Setelah Tanam (HST)

Gambar 11. Nilai Evapotranspirasi Potensial

Faktor-faktor yang dominan mempengaruhi evapotranspirasi adalah radiasi panas matahari dan suhu, kelembaban relatif dan angin, dan secara umum besarnya evapotranspirasi akan meningkat ketika suhu, radiasi panas matahari, kelembaban, dan kecepatan angin bertambah besar. Berdasarkan pada Gambar 11, nilai evapotranspirasi potensial selama 16 hari penanaman berada pada rentang 3,33 hingga $5,72 \mathrm{~mm} /$ hari dan umumnya pada rentang 4 hingga $5 \mathrm{~mm} /$ hari. Nilai evapotranspirasi terbesar yaitu pada hari ketujuh dengan nilai 5,72 $\mathrm{mm} /$ hari dan terendah pada hari kedua dengan nilai $3,33 \mathrm{~mm} / \mathrm{hari}$.

\section{Koefisien Tanaman}

Menurut (Allen et al., 1998b) beberapa hal yang mempengaruhi nilai $\mathrm{Kc}$ adalah jenis tanaman, iklim, evaporasi tanah dan fase pertumbuhan tanaman. Nilai Kc yang diukur pada penelitian ini adalah nilai Kc tanaman kangkung hanya saat fase pertumbuhan. Gambar 12 menunjukkan perbandingan hasil nilai Kc aktual dengan $\mathrm{Kc}$ teoritis menurut Allen et al. (1998).

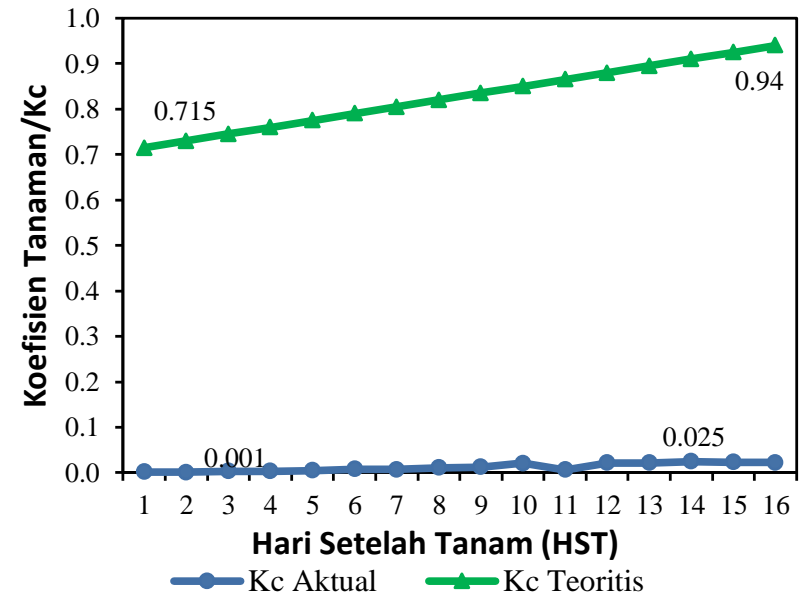

Gambar 12. Nilai Kc Aktual dan Kc Teoritis

Berdasarkan grafik tersebut, nilai Kc aktual seluruhnya lebih rendah dibandingkan dengan nilai Kc teoritis. Hal tersebut disebabkan karena pada sistem hidroponik ini penggunaan air lebih rendah dan tempat yang digunakan cenderung lebih kecil. Dapat dikatakan penggunaan air untuk memenuhi kebutuhan air tanaman kangkung dengan sistem hidroponik ini lebih hemat karena adanya sirkulasi sehingga air yang terbuang sangat sedikit.

Nilai Kc teoritis yang digunakan ini merupakan nilai Kc dari bayam karena belum diketahuinya literatur nilai Kc teoritis dari tanaman kangkung. Selain itu, bayam dan kangkung merupakan satu divisi dan kelas sehingga Kc tanaman bayam dijadikan acuan. Literatur dari (Kurnia, 2004) menyatakan bahwa nilai koefisien tanaman $(\mathrm{Kc})$ pada awal pertumbuhan paling rendah dan mencapai maksimal pada saat pembungaan atau pembuahan, kemudian berkurang menjelang fase pemasakan. Fase pertumbuhan tanaman maksimal dibutuhkan air dalam jumlah yang cukup banyak. Oleh karena itu, fase-fase pertumbuhan tanaman, lamanya setiap fase pertumbuhan, dan fase kritis pertumbuhan perlu diketahui agar perencanaan pemberian air, baik jumlah maupun waktunya lebih tepat.

\section{Konsumsi Nutrisi}

Penelitian ini menggunakan pupuk $\mathrm{AB}$ mix granular. Pupuk $\mathrm{AB}$ mix granular dilarutkan terlebih dahulu untuk digunakan sebagai biang nutrisi. Tujuan dilakukannya pelarutan $\mathrm{AB}$ mix terlebih dahulu untuk meminimalisir pengendapan yang dapat menyebabkan penyumbatan pada jaringan pipa. Juga didukung oleh hasil penelitian dari (Yunindanova, Darsana, Ardianto, \& Putra, 2018) yang menyebutkan bahwa penggunaan 
nutrisi $\mathrm{AB}$ mix memberikan hasil yang optimal. Nutrisi AB-mix mengandung berbagai unsur hara makro dan mikro yang dapat diserap baik oleh tanaman. Kandungan nutrisi AB-mix terbagai menjadi dua formula yaitu formula A dan formula $\mathrm{B}$ yang masing-masing telah disebutkan pada bab tinjauan pustaka. Penggunaan nutrisi selama penelitian disajikan pada Tabel 1.

Tabel 1. Penambahan Nutrisi

\begin{tabular}{ccc}
\hline HST & $\begin{array}{c}\text { Penggunaan } \\
\text { Nutrisi (ml) }\end{array}$ & $\begin{array}{c}\text { Sisa Pekatan } \\
\text { Nutrisi (ml) }\end{array}$ \\
\hline $\mathbf{1}$ & 4200 & \\
$\mathbf{2}$ & 400 & \\
$\mathbf{6}$ & 400 & \\
$\mathbf{9}$ & 400 & 3940 \\
$\mathbf{1 0}$ & 500 & \\
$\mathbf{1 1}$ & 400 & \\
$\mathbf{1 2}$ & 200 & \\
$\mathbf{1 5}$ & 200 & \\
$\mathbf{1 6}$ & 1100 & $\mathbf{3 9 4 0}$ \\
\hline Jumlah & $\mathbf{7 8 0 0}$ & $\mathbf{3 8 6 0}$ \\
\hline \multicolumn{2}{l}{ Total Penggunaan Nutrisi }
\end{tabular}

Berdasarkan pada Tabel di atas, total penggunaan nutrisi selama penelitian adalah sebesar $3860 \mathrm{ml}$. Penambahan nutrisi tidak dilakukan setiap hari. Penambahan nutrisi ini hanya diperlukan untuk menjaga nilai EC pada larutan nutrisi. Umumnya penambahan ini dilakukan setelah air pada tandon nutrisi diisi kembali. Penambahan nutrisi dimaksudkan untuk mengembalikan larutan nutrisi yang berkurang akibat penyerapan unsur hara oleh tanaman dan penguapan air, agar nilai EC larutan nutrisi dapat terpantau dengan pengurangan larutan yang berkurang dan nilai EC yang berubah setiap penambahan air pada tandon.

Pemberian nutrisi terbesar pada sistem rakit apung ini adalah ketika awal masa tanam. Harga untuk satu bungkus nutrisi seberat $1,7 \mathrm{~kg}$ yang digunakan pada penelitian ini adalah Rp90.000,00. Nutrisi $A B$ mix $1,7 \mathrm{~kg}$ tersebut masing-masing dilarutkan pada air sebanyak 5 liter. Biaya untuk nutrisi selama satu masa tanam ini adalah $\mathrm{Rp}$ 34.941,18. Hasil tersebut adalah hasil setelah pengurangan pekatan nutrisi yang tersisa setelah tanaman kangkung dipanen.

Menurut (Susila, 2006) pemberian pupuk untuk kangkung darat jika bertanam secara konvensional adalah urea $187 \mathrm{~kg} / \mathrm{ha}, 311 \mathrm{~kg} / \mathrm{ha} \mathrm{SP}$ 36 dan $112 \mathrm{~kg} / \mathrm{ha} \mathrm{KCl}$ serta penambahan pupuk kandang sebanyak 10 ton/ha pada awal penanaman. Penggunaan pupuk tersebut bila dijumlahkan menjadi $10610 \mathrm{~kg} / \mathrm{ha}$. Penggunaan nutrisi $\mathrm{AB}$ mix ini berdasarkan hasil penelitian ini setelah dikonversikan pada satuan pada satuan $\mathrm{kg}$ adalah sebanyak $0,66 \mathrm{~kg}$ untuk ukuran sistem $4,1125 \mathrm{~m}^{2}$.

\section{Konsumsi Energi}

Konsumsi energi yang dihitung pada penelitian ini adalah total penggunaan energi listrik dari pompa dan aerator yang selalu dinyalakan karena tidak menggunakan sistem penjadwalan penyalaan pompa dan aerator. Tabel 2 menunjukkan jumlah konsumsi energi listrik selama satu masa tanam.

Tabel 2. Konsumsi Energi Sistem Rakit Apung

\begin{tabular}{cccc}
\hline Alat & $\begin{array}{c}\text { Daya } \\
\text { (Watt) }\end{array}$ & $\begin{array}{c}\text { Lama } \\
\text { Waktu } \\
\text { Nyala (Jam) }\end{array}$ & $\begin{array}{c}\text { Jumlah } \\
\text { Energi } \\
\text { Listrik } \\
\text { (KWH) }\end{array}$ \\
\hline Pompa & 50 & 388 & 19,4 \\
Aerator & 32 & 388 & 12,416 \\
\hline \multicolumn{3}{c}{ Jumlah } & 31,816 \\
\hline
\end{tabular}

Total energi listrik yang digunakan selama satu masa tanam yang terhitung selama 16 hari ini adalah sebanyak 31,816 kWh. Berdasarkan keterangan dari laman web PLN, tarif dasar listrik adalah Rp1.467,28. Maka jumlah biaya yang dikeluarkan selama satu masa tanam ini adalah Rp46.682,98. Hasil tersebut tentu saja dapat dimaksimalkan dengan sistem penjadwalan untuk penyalaan pompa dan aerasi. Lama aerasi terbukti mempengaruhi hasil pertumbuhan tanaman. Penelitian dari (Ningrum et al., 2014), yang meneliti pengaruh lama aerasi terhadap pertumbuhan tanaman menyebutkan bahwa lama aerasi ideal adalah pada perlakukan nyala 15 menit dan mati 60 menit. Sementara perlakuan dengan pompa selalu dinyalakan selama 24 jam memperoleh hasil tanaman kedua terbaik namun biaya yang dikeluarkan lebih tinggi.

\section{Analisis Keseragaman}

Keseragaman yang dihitung pada penelitian ini merupakan keseragaman dari pertumbuhan kangkung, keseragaman produksi ketika pemanenan (tinggi tanaman, panjang akar dan bobot basah tanaman) dan keseragaman irigasi sistem rakit apung yang digunakan. 


\section{Analisis Keseragaman Pertumbuhan Tanaman}

Keseragaman pertumbuhan dihitung berdasarkan tinggi tanaman ketika pengukuran setiap tiga hari. Tinggi tanaman ini diukur dari pangkal netpot hingga ke ujung daun tertinggi. Tinggi tanaman merupakan ukuran tanaman yang sering diamati sebagai indikator pertumbuhan maupun sebagai parameter karena tinggi tanaman ini merupakan ukuran pertumbuhan yang mudah dilihat (Komalasari, 2016). Gambar berikut menunjukkan grafik hasil pengukuran pertumbuhan tanaman.

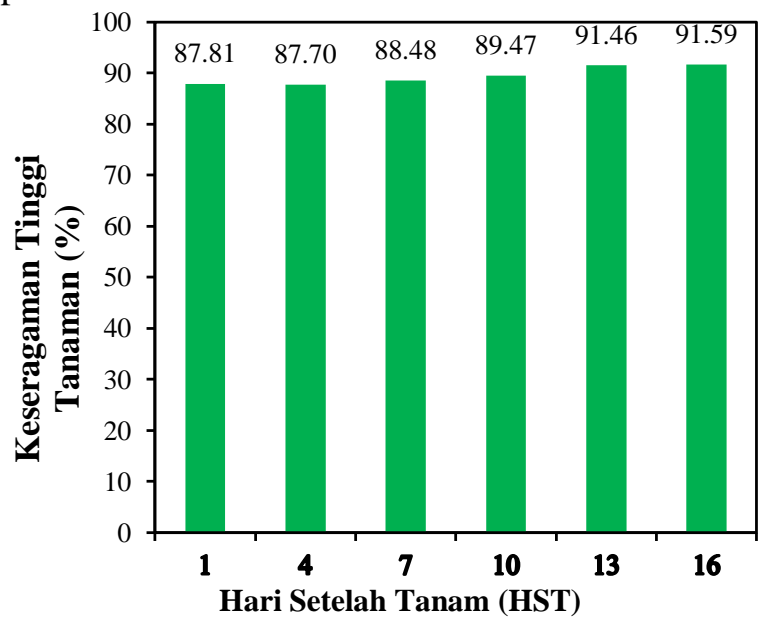

Gambar 13. Keseragaman Pertumbuhan Tanaman

Berdasarkan pada gambar di atas, hasil nilai keseragaman pertumbuhan tanaman berada pada rentang $87,7 \%$ hingga $91,59 \%$. Keseragaman pertumbuhan ini cenderung meningkat di setiap pengukurannya yang menandakan bahwa keseragaman tinggi tanaman semakin membaik. Nilai keseragaman tersebut termasuk pada kriteria keseragaman baik bahkan hampir mencapai sangat baik pada 16 HST. Tanaman dipanen pada 16 HST, berdasarkan pada pendapat dari (Susila, 2006) yang menyebutkan bahwa tanaman kangkung dapat dipanen ketika umur 25-27 HST atau ketika tinggi $20-25 \mathrm{~cm}$.

\section{Keseragaman Hasil Produksi}

Keseragaman hasil produksi merupakan hasil dari perhitungan ketika panen yaitu keseragaman tinggi tanaman, keseragaman panjang akar dan keseragaman bobot tanaman. tabel di bawah ini menunjukkan grafik keseragaman untuk hasil produksi meliputi tinggi tanaman, panjang akar dan bobot tanaman.

Tabel 3. Keseragaman Produksi Tanaman

$\begin{array}{ccc}\text { Parameter } & \text { Rerata } & \begin{array}{c}\text { Keseragaman } \\ (\%)\end{array}\end{array}$

\begin{tabular}{ccc}
\hline $\begin{array}{c}\text { Tinggi Tanaman } \\
(\mathbf{c m})\end{array}$ & 64,28 & 92,16 \\
$\begin{array}{c}\text { Panjang Akar } \\
(\mathbf{c m})\end{array}$ & 36,59 & 88,21 \\
$\begin{array}{c}\text { Bobot Tanaman } \\
\text { (gram) }\end{array}$ & 164,53 & 75,75 \\
\hline
\end{tabular}

Berdasarkan hasil penelitian, tanaman dipanen ketika hari ke 16 setelah pindah tanam. Berbagai indikator seperti tinggi tanaman yang keseluruhannya sudah melebihi $25 \mathrm{~cm}$ serta daun yang lebat sudah terpenuhi. Sesuai dengan pernyataan dari (Susila, 2006) yang menyebutkan bahwa kangkung darat bisa dipanen apabila secara visual pertumbuhan batangnya sudah besar, berdaun banyak, dan tinggi tanamannya sudah mencapai $20-25 \mathrm{~cm}$, beberapa pendapat juga menyatakan bahwa kangkung sudah bisa dipanen pada umur sekitar 25 - 27 HST.

Tinggi tanaman ketika panen memiliki ratarata sebesar 64,28 $\mathrm{cm}$ dengan keseragaman $92,16 \%$. Berdasarkan pada kriteria keseragaman menurut ASAE, keseragaman sebesar 92,16\% termasuk ke dalam kategori baik. Peningkatan tinggi tanaman kangkung dapat disebabkan oleh beberapa faktor seperti nutrisi yang diberikan. Kesesuaian nutrisi yang diberikan dengan kebutuhan dan umur tanaman sangat berpengaruh terhadap pertumbuhan tanaman.

Rata-rata panjang akar adalah $36,59 \mathrm{~cm}$ dengan nilai terpanjang adalah $47,2 \mathrm{~cm}$ dan terendah $23,5 \mathrm{~cm}$ dengan keseragaman $88,21 \%$. Keseragaman tersebut masuk pada kategori keseragaman baik. Akar dari tanaman kangkung yang ditanam dengan sistem fertigasi rakit apung ini cenderung berbentuk lurus dan lebat, berbeda jika dibandingkan dengan akar pada sistem NFT dan DFT yang lebih melebar. Tampak penampilan akar dari hasil penelitian ini juga terlihat segar dan berwarna putih cerah. Hal tersebut dapat dipengaruhi oleh adanya aerator pada sistem rakit apung yang digunakan sehingga aliran oksigen dalam air tetap terjga. Oksigen terlarut yang cukup dalam air akan membantu perakaran tanaman dalam mengikat oksigen. Bila kadar oksigen terlarut cukup tinggi, maka proses respirasi akan lancar dan energi yang dihasilkan akar cukup banyak untuk menyerap hara yang dapat diserap tanaman. Semakin panjang dan luas akar maka jumlah unsur hara dan air yang terserap lebih banyak menyebabkan proses fotosintesis lebih baik (Fikri, Indradewa, \& Putra, 2015).

Nilai rata-rata bobot basah tanaman kangkung ketika panen yaitu 164,53 gram dengan hasil panen paling besar yaitu 263,5 gram dan 
paling kecil yaitu 81,5 gram dalam sebuah netpot yang berisi 5 buah tanaman kangkung. Keseragaman bobot yang diperoleh adalah 75,75\% dan masuk pada kategori baik. Jumlah total berat kangkung untuk 64 sampel netpot ini adalah sebesar $10,53 \mathrm{~kg}$ dengan luasan sistem yang digunakan adalah $4,1125 \mathrm{~m}^{2}$.

Bobot basah kangkung yang terbilang besar ini disebabkan karena penyerapan unsur hara lebih cepat karena perakaran yang lebat dan panjang. Produktivitas tanaman kangkung jenis Bangkok LP-1 yang tertera pada kemasan benihnya adalah sebesar 25-30 ton/ha atau jika dikonversikan menjadi 2,5-3 kg/m ${ }^{2}$. Produktivitas kangkung berdasarkan hasil penelitian ini adalah sebesar 72,8 ton/ha atau $7,28 \mathrm{~kg} / \mathrm{m}^{2}$ yang artinya hasil produktivitas kangkung yang dihasilkan dengan sistem ini lebih besar $2-3$ kali di bandingkan dengan penanaman secara konvensional. Hal ini didukung dengan pernyataan (Bachri, 2017), produksi kangkung dengan budi daya secara hidroponik ini berpotensi menghasilkan bobot kangkung hampir tiga kali lipat dibandingkan dengan penanaman secara konvensional.

\section{Analisis Efisiensi Penggunaan Air (Water Used Efficiency)}

Water Used Efficiency atau efisiensi penggunaan air merupakan perbandingan antara hasil total bobot tanaman dengan total penggunaan air selama satu masa tanam. Berdasarkan pada hasil total bobot tanaman dan penggunaan air konsumtif yang telah dibahas sebelumnya, total bobot tanaman adalah sebesar 29,94 $\mathrm{kg}$ dengan total penggunaan air konsumtif $0,30063 \mathrm{~m}^{3}$ maka nilai efisiensi penggunaan air pada penelitian ini adalah sebesar $99,6 \mathrm{~kg} / \mathrm{m}^{3}$. Berarti untuk $1 \mathrm{~m}^{3}$ air dapat digunakan untuk menghasilkan $99,6 \mathrm{~kg}$ tanaman kangkung. Hasil tersebut jauh lebih besar apabila dibandingkan dengan efisiensi penanaman kangkung di lahan dengan media tanah. Semakin besar bobot tanaman maka semakin besar pula efisiensi penggunaan airnya, sedangkan semakin tinggi penggunaan air semakin rendah efisiensi penggunaan airnya. Sistem fertigasi rakit apung ini merupakan sistem irigasi bawah permukaan, yang artinya air langsung mengenai akar tanaman dan selalu bersirkulasi. Hal tersebut yang mengakibatkan air yang digunakan tidak ada yang terbuang kecuali terjadi evapotranspirasi sehingga penggunaan air sangat efisien namun hasil produksi yang diperoleh sangat tinggi.

\section{SIMPULAN}

Jumlah total energi yang digunakan selama satu masa tanam ini adalah sebanyak $31,816 \mathrm{kWH}$, penggunaan air konsumtif selama satu masa tanam ini adalah sebanyak 300,63 liter, jumlah konsumsi nutrisi adalah sebanyak $3860 \mathrm{ml}$. Kinerja sistem ditinjau dari nilai keseragaman adalah termasuk pada kategori cukup baik untuk bobot tanaman, baik untuk pertumbuhan tanaman, tinggi tanaman panen dan panjang akar. Kangkung yang dihasilkan memiliki nilai efisiensi penggunaan air sebesar $99,6 \mathrm{~kg} / \mathrm{m}^{3}$ dan produktivitas lahan dengan menggunakan sistem rakit apung ini adalah 7,28 $\mathrm{kg} / \mathrm{m}^{2}$ atau 72,8 ton/ha. Sistem fertigasi rakit apung yang digunakan sudah dianggap lebih baik dibandingkan jika menanam secara konvensional dengan media tanah.

\section{UCAPAN TERIMA KASIH}

Penulis mengucapkan terima kasih pada Kementerian Riset, Teknologi dan Pendidikan Tinggi Republik Indonesia yang telah mendanai riset ini melalui skema Penelitian Dasar Unggulan Perguruan Tinggi tahun 2018 dengan nomor kontrak 681/UN6.N/LT/2018.

\section{DAFTAR PUSTAKA}

Allen, R. G., Pereira, L. S., Raes, D., \& Smith, M. (1998a). Crop evapotranspiration: Guidelines for computing crop requirements. Irrigation and Drainage Paper No. 56, FAO, (56), 300. https://doi.org/10.1016/j.eja.2010.12.001

Allen, R. G., Pereira, L. S., Raes, D., \& Smith, M. (1998b). Crop Evapotranspiration. In FAO Irrigation and Drainage Paper No. 56 (Vol. $56)$. 1187(05)80058-6

Bachri, Z. (2017). Kangkung Hidroponik. Jakarta: Penebar Swadaya.

Bafdal, N., \& Dwiratna, S. (2018). Water Harvesting System as an Alternative Appropriate Technology to Supply Irrigation on Red Oval Cherry Tomato Production. International Journal on Advanced Science, Engineering and Information Technology, $8(2)$, 561. https://doi.org/10.18517/ijaseit.8.2.5468

Bafdal, N., Dwiratna, S., \& Kendarto, D. R. (2017). Impact of water use on paprika (Capsicum annum) by using fertigation and autopot system combined with numerous growing 
media. Asian Journal of Plant Sciences, 16(3), $149-159$. https://doi.org/10.3923/ajps.2017.149.159

Bafdal, N., Dwiratna, S., \& Kendarto, D. R. (2018). Differences Growing Media In Autopot Fertigation System And Its Response To Cherry Tomatoes Yield. Indonesian Journal of Applied Sciences, 7(3), 63-68. https://doi.org/10.24198/ijas.v7i3.14369

Bafdal, N., Dwiratna, S., Kendarto, D. R., \& Suryadi, E. (2017). Rainwater Harvesting As a Technological Innovation to Supplying Crop Nutrition through Fertigation. International Journal on Advanced Science, Engineering and Information Technology, 7(5), 1970. https://doi.org/10.18517/ijaseit.7.5.3262

Dwiratna, S., \& Bafdal, N. (2016). Penjadwalan Irigasi Berbasis Neraca Air Pada Sistem Pemanenan Air Limpasan Permukaan Untuk Pertanian Lahan Kering. Jurnal Keteknikan Pertanian, $\quad 04(2), \quad 1-8$. https://doi.org/10.19028/jtep.04.2.219-226

Dwiratna, S., Bafdal, N., \& Kendarto, D. R. (2017). Kinerja Sistem Fertigasi Autopot pada Budidaya Tomat Cherry The Performance of Autopot Fertigation System on Cherry Tomato Cultivation. Indonesian Journal of Applied Science, 7(3), 56-60.

Fikri, M. S., Indradewa, D., \& Putra, E. T. S. (2015). Pengaruh Pemberian Kompos Limbah Media Tanam Jamur pada Pertumbuhan dan Hasil Kangkung Darat (Ipomoea reptans Poir.). Jurnal Vegetalika, 4(2), 79-89.

Hidayati, N., Rosawanti, P., Yusuf, F., \& Hanafi, N. (2017). Kajian Penggunaan Nutrisi Anorganik terhadap Pertumbuhan Kangkung (Ipomoea reptans Poir) Hidroponik Sistem Wick. Daun: Jurnal Ilmiah Pertanian Dan Kehutanan, 4(2), 75-81. https://doi.org/10.33084/daun.v4i2.81

Iqbal, M. (2016). Simpel Hidroponik. Yogyakarta: Andi Offset.

Komalasari, D. (2016). Modifikasi dan Uji Kinerja Sistem Autopot Menggunakan Media Tanam Arang Sekam dan Hukum untuk Budidaya Tanaman Selada Merah (Lactuca sativa Lollo rossa.). Universitas Padjadjaran.

Kresna, I. G. P., Sukerta, I. M., \& Suryana, I. M. (2013). Pertumbuhan dan Hasil Beberapa Varietas Tanaman Kangkung Darat (Ipomea Reptans P.) Pada Tanah Alluvial Coklat Kelabu. Agrimeta: Jurnal Pertanian
Berbasis Keseimbangan Ekosistem, 87-92.

Kurnia, U. (2004). Prospek Pengairan Pertanian Tanaman Semusim Lahan Kering.

Kurniasih, A. (2011). Pengaruh Penggunaan Aerator Pada Hidroponik Sistem Rakit Apung (Floating Hidroponic System/Fhs) Dan Kultur Air (Deep Flow Technique/Dft) Terhadap Pertumbuhan Dan Hasil Beberapa Tanaman Sayuran. Universitas Sebelas Maret.

Michael, A. M. (2001). Theory and Practice. London: Vikas Publishing House PVT. LTD.

Morgan, L. (2000). The pH Factor in Hydroponics. Corvaillis.

Mori, K. (2006). Hidrologi untuk Pengairan. Jakarta: Pradnya Paramita.

Muharomah, R., Setiawan, B. I., \& Purwanto, M. Y. (2017). Konsumsi dan Kebutuhan Air Selada pada Teknik Hidroponik Sistem Terapung. Jurnal Irigasi, 12(1), 47-54.

Nazaruddin. (2003). Budi Daya dan Pengantar Panen Sayuran Dataran Rendah. Jakarta: Penebar Swadaya.

Ningrum, D. Y., Triyono, S., \& Tusi, A. (2014). Pengaruh Lama Aerasi Terhadap Pertumbuhan dan Hasil Tanaman Sawi (Brassica Juncea L.) pada Hidroponik DFT (Deep Flow Technique). Jurnal Teknik Pertanian Lampung, 3(1), 83-90.

Nugrahani, L. (2018). Kajian Perubahan Suhu Lingkungan terhadap EC dan pH Larutan Nutrisi dalam autopot pada Pertumbuhan Tanaman Tomat Cherry (Solanum Lycopersicum Var.Cerasiforme). Fakultas Teknologi Industri Pertanian. Universitas Padjadjaran.

Nurrohman, M., Suryanto, A., \& Puji, K. (2014). Penggunaan Fermentasi Ekstrak Paitan (Tithonia Diversifolia L.) Dan Kotoran Kelinci Cair Sebagai Sumber Hara Pada Budidaya Sawi (Brassica Juncea L.) Secara Hidroponik Rakit Apung. Produksi Tanaman, 2(8), 649-657.

Palada, M. C., \& Chang, L. C. (2003). Suggested Cultural Practices for Vegetable Amaranth. Vegetable Reseach and Development Center.

Paradiso, R., Buonomo, R., Dixon, M. A., Barbieri, G., \& De Pascale, S. (2014). Soybean cultivation for Bioregenerative Life Support Systems (BLSSs): The effect of hydroponic system and nitrogen source. Advances in Space Research, 53(3), 574-584. https://doi.org/10.1016/j.asr.2013.11.024

Sapei, A. (2003). Uniformity dan Efisiensi Irigasi 
Sprinkler dan Drip. Bogor.

Subandi, M., Salam, N. P., \& Frasetya, B. (2014). Pengaruh Berbagai Nilai EC ( Electrical Conductivity ) terhadap Pertumbuhan dan Hasil Bayam (Amaranthus Sp .) pada Hidroponik Sistem Terapung ( Floating Hydroponic System ). Vegetalika, 9(2), 136152. https://doi.org/10.1037/h0036349

Suryani, R. (2015). Hidroponik Budidaya Tanaman Tanpa Tanah. Yogyakarta: Arcitra.

Susila, A. D. (2006). Panduan Budidaya Tanaman Sayuran. Institut Pertanian Bogor.

Sutiyoso, Y. (2018). 100 Kiat Sukses Hidroponik. Depok: Trubus Swadaya.

Widianty, S. (2016). Kajian Perubahan Suhu, pH, dan Electric Conductivity dalam Larutan Nutrisi pada Pertumbuhan Tanaman Paprika Hidroponik di Autopot.

Yunindanova, M. B., Darsana, L., Ardianto, D. A. N., \& Putra, P. (2018). Respon Pertumbuhan dan Hasil Tanaman Seledri terhadap Nutrisi dan Naungan Menggunakan Sistem Hidroponik Rakit Apung. Jurnal Agroteknologi, 9(1), 1-8. 